\title{
ESTOICISMO E EPICURISMO EM ROMA
}

\author{
MARIA DA GLORIA NOVAK* \\ Faculdade de Filosofia, Letras e Ciências Humanas \\ da Universidade de São Paulo
}

\begin{abstract}
RESUMO: Todo homem quer ser feliz. Estoicismo e epicurismo, filosofias da natureza, filosofias morais, dão respostas à inquietação do homem que sonha com a serenidade da alma. Costuma-se opor epicurismo e estoicismo, pois suas verdades primordiais e suas regras de vida são diferentes. O primeiro procura a salvação da sociedade pela dependência do homem a uma Providência divina; o segundo, a liberdade do homem, tornando-o seu próprio senhor. Se o Deus estóico, Razão, criou e governa o mundo, os Deuses epicúrios, modelo - perfeito - do comportamento do sábio, não o criaram nem interferem nele.
\end{abstract}

PALAVRAS-CHAVE: Roma; epicurismo e estoicismo; liberdade e destino; mortalidade e imortalidade.

Para compreender bem o sentido do estoicismo e do epicurismo, nada melhor que estudá-los desde sua origem: desde o momento em que nasceram em Atenas essas filosofias morais da natureza, essas filosofias que tiveram tão grande expressão em Roma e no Ocidente, ousaria eu dizer, até os nossos dias. De fato o estoicismo, tal como o epicurismo, nasceu como resposta moral às dúvidas de cidadãos que se inquietavam com relação ao seu comportamento e à sua felicidade, num mundo conturbado, onde cada qual desejava ser feliz mas não sabia como agir. Opõem-se, no entanto, os dois sistemas, quanto aos seus postulados e às suas regras de conduta: os Deuses do epicurismo, a liberdade do sábio, o láthe biósas não encontram correspondentes nem na razão universal, nem no determinismo nem na alma imortal dos estóicos: mas o fato é que ambos os sistemas dão as respostas esperadas.

É de incerteza e perturbação o momento político e religioso, e igualmente conturbado é o momento filosófico, pelos fins do século IV, início do século III a.C. na Hélade. Ainda existem e são mais ou menos fiéis a Academia e o Liceu. As Escolas Socráticas menores, no entanto, falseiam a doutrina de Sócrates. 
Diodoro Cronos e os megáricos levam às últimas conseqüências a dúvida socrática.

Os cínicos transformam-na em sarcasmo ao mesmo tempo em que negam as convenções sociais. Proclamam a igualdade de todos os homens em face do valor moral. Intitulam-se cidadãos do mundo e opõem aos sábios os insensatos. $\mathrm{O}$ bem é para eles o sofrimento, a renúncia. $O$ mal são os prazeres que ultrapassam as necessidades naturais, principalmente os prazeres que resultam da vida social. Todos conhecemos o cínico Diógenes de Sinope e as histórias que sobre ele se contam.

Aristipo e os cirenaicos, baseando-se no conhece-te a ti mesmo, consideram o homem como juiz absoluto, e o prazer como fim e meta. A realidade verdadeira é impossível de conhecer, visto que se constitui de movimento. Além das nossas impressões há um valor que é o prazer, mas só podemos medi-lo nos seus efeitos. $\mathrm{O}$ prazer verdadeiro, no entanto, só o sábio pode senti-lo: e o sentirá tanto em meio à dor como em meio às alegrias.

Os céticos, discípulos de Pírron de Élis e herdeiros dos sofistas, procuram na negação a sabedoria: não julgar, não falar, não definir, ser indiferente e conseguir a ausência de perturbação. Nem as sensações nem os julgamentos podem ou dizer a verdade ou enganar-se: tudo é igualmente indiferente, equilibrado, indeciso. Assim, o homem não terá opinião, nem tendência, nem agitação de espírito: oudèn mâllon: tanto sim como não, nem sim nem não; e a suspensão de julgamento leva ao silêncio. O ideal do sábio é o equilíbrio que nada pode perturbar, a impassibilidade total. De fato, se as aparências enganam, se tudo é relativo, por que preocupar-se? O ceticismo, em suma, é na origem uma disciplina moral cujo fim é a quietude (ataraxía e apátheia), como, por exemplo, se lê em Diógenes Laércio (IX 106-8).

Todos, enfim, se fecham em si mesmos. Embora a reflexão que se opera nesse momento não separe inteiramente da sociedade o indivíduo, a sociedade estende-se para além dos limites da pólis. E o sábio helenístico, de maneira geral, seja qual for a sua Escola, sonha com a auto-suficiência e a serenidade. Todo homem quer ser feliz, mas a felicidade positiva não existe. Não se consegue uma definição da verdade e do bem, e tanto faz viver ou morrer, como afirma Hegésias de Cirene, apelidado Peisithánatos ("Conselheiro da morte").

Este é o cenário de Atenas quando ali surgem o epicurismo e o estoicismo, que tanto influenciarão Roma.

Epicuro de Samos (342/341-271/270), cidadão ateniense, teria sido discípulo do platônico Pânfilo (Cic., ND I 26, 72). Dos dezoito aos vinte anos, efebo em Atenas e companheiro de Menandro, teria ouvido lições na Academia e no Liceu. A seguir, por razões políticas não pode voltar a Samos e passa os anos seguintes em 
Colofão, Mitilene e Lâmpsaco; provavelmente vai também a Rodes. Elabora o que podemos chamar a sua teoria moral. Em 306 volta a Atenas e cria a Escola do Jardim.

Zenão de Cício (335-263), o criador do estoicismo, teria chegado a Atenas por volta de 311. Discípulo de Crates de Tebas, o Cínico, aprendeu que o sábio vive de acordo com a natureza e em sociedade consigo mesmo. Teria ouvido, ainda, lições dos platônicos Polemão de Atenas e Xenócrates; e também dos megáricos Estilpão e Diodoro Cronos. Por volta de 300 ou 294, teria começado a ensinar publicamente junto ao Pórtico das Pinturas. Sábio, discreto e respeitado, morreu como viveu e foi dono de sua morte como fora dono de sua vida (DL VII 2.15).

O epicurismo consistiria numa reelaboração de idéias democritianas e cirenaicas, transformadas pela disciplina pirronista. O estoicismo por sua vez estaria mais próximo da Escola Cínica, embora não se atenham os estóicos à idéia de ascetismo, os epicuristas à de prazer.

São ambos, estoicismo e epicurismo, doutrinas de reconciliação do homem com a natureza. Tentam explicar o homem e o mundo por meio de sistemas que compreendem uma lógica e uma física que levam a uma ética. Ensinam critérios de certeza e regras de vida. Assim, têm objetivos morais: definição do conceito de sábio e felicidade individual; e implicam ambos uma atitude religiosa.

Se, porém, são os mesmos o seu ponto e partida e o seu objetivo (conhecimento e aceitação da natureza, e tranqüilidade de espírito, que repousa sobre o saber), diferentes são as suas verdades primordiais e as suas regras de vida.

Costuma-se opor epicurismo a estoicismo. E, embora a oposição seja bem definida, o epicurismo na origem se oporia mais ao Aristóteles perdido e a Platão. ${ }^{1}$ Lêse em Diógenes Laércio (X 24-5.27) que Metrodoro escreveu contra os dialéticos, contra os sofistas e contra Demócrito; que Hermarco escreveu contra Platão e contra Aristóteles; Epicuro, contra os megáricos. Não consta que houvessem escrito contra os estóicos. Ao contrário, o estoicismo opõe-se ao epicurismo: surgiu mais tarde e o contradiz. Entretanto, vejamos.

Se o estóico participa da vida política, o epicurista em geral vive escondido, o que me parece fundamental. Esse dado explicaria talvez, em grande parte, a estabilidade da doutrina epicúria e a constante evolução do estoicismo através dos tempos.

Se no estoicismo o vazio infinito é exterior ao mundo e este é único, no epicurismo infinitos mundos existem e os átomos que os compõem movem-se no vazio infinito. Se esses átomos são, no epicurismo, insecáveis, e essa afirmação é basilar na doutrina, o estoicismo, ao contrário, admite a divisão da matéria ao infinito. 
Se no estoicismo a natureza se identifica a um Deus único, imortal e feliz, se os fatos se ligam e se passam de acordo com o destino e a necessidade; se tudo é governado pelo Deus, hálito de fogo, espírito ou lógos, autor do universo, e o homem deve submeter-se a essa razão universal (DL VII 147-9), no epicurismo os Deuses, eternos, perfeitos, admiráveis e imitáveis, nada têm a ver com a vida humana ou com os fenômenos da natureza (Pyth. \$97). A afirmação de sua existência é coerente com a doutrina epicúria: correspondem a uma prenoção gravada em todos os homens e a uma necessidade de equilíbrio na natureza: são o oposto que contrabalança a existência mortal.

Se o sábio estóico deve tornar-se passivo e procurar a total conformação diante de fatos que não dependem dele (em vista da absoluta necessidade dominante), o sábio epicurista, dono dos seus atos, é verdadeiramente o agente moral de sua ataraxia.

Se o estóico tem como imortal sua alma, enquanto emanação da alma do mundo e, por conseguinte, parcela do lógos divino, ${ }^{2}$ se, para ele, a mesma ordem da natureza voltará a realizar-se necessariamente, a alma para o epicurista é mortal e a mesma ordem da natureza pode voltar a verificar-se mas não voltará necessariamente.

Se o estoicismo tem a explicação de todos os fenômenos, o epicurismo contenta-se em saber que todos são explicáveis fisicamente, sem a intervenção milagrosa de uma vontade divina: muitas são as explicações possíveis e não há razão para que se prefira uma a outra. Enfim, da saúde da alma depende a felicidade, e este é o objetivo de ambas as filosofias. A importância do conhecimento reside unicamente na sua utilidade moral.

Aliás, é característica da nova fase do pensamento a atitude que Robin chama indifférence spéculative; predomina a preocupação prática; também os cínicos, os cirenaicos e os megáricos são pragmáticos: o saber nada é se não serve à ação (Robin, 1948, 376).

E o atomismo de Leucipo e Demócrito parece a Epicuro a única explicação capaz de garantir ao homem a sonhada paz de espírito, e nele se baseiam os argumentos fundamentais da física epicúria. Há no universo três infinitos, que compõem um todo infinito: átomos, vazio e tempo: eternos e infinitos.

O vazio é uma extensão necessariamente infinita. Compreende os átomos e existe onde quer que estes não estejam, porém não os penetra pois estes são insecáveis.

Os átomos são corpos sólidos e indivisíveis. Movem-se no vazio e o seu número, como vimos, é infinito. Inúmeras, mas não infinitas como pretendia Demócrito, são as suas formas: e inúmeros os seus tamanhos. Pequeníssimos, po- 
rém, fogem à nossa percepção. O que os torna insecáveis e indissolúveis é a sua plenitude absoluta. As suas qualidades portanto são forma, tamanho e tudo o que é necessariamente ligado à forma; e também peso. Possuem, ainda, quando em composição, a capacidade de continuar em movimento. Mas não possuem nem cor, nem odor, nem sabor, nem temperatura; nem sensibilidade.

Os seres formam-se a partir do encontro dos átomos e, como todos os seres se compõem de átomos e neles se decompõem, nada vem do nada e nada acaba em nada; e, pois, a quantidade total de matéria é sempre a mesma.

Eternos são apenas os três infinitos e os Deuses. Assim, todos os compostos estão fadados a decompor-se; e também o nosso mundo, que não é único no universo, e todos os outros mundos. Só os Deuses não se decompõem, o que contradiria a sua eternidade: e não se decompõem pelo fato de que não têm identidade material, mas formal.

Ora, a Vrbs não é estranha à filosofia e teria sofrido desde cedo influências pitagóricas.

Durante o período helenístico da literatura (240-79), sobretudo a partir do século II, vem a receber, não sem reação, as filosofias da natureza, estoicismo e epicurismo, que aí vieram a ter importância tão grande quanto na Hélade.

O caminho para a filosofia do século I é preparado lentamente. Em 173 (ou em 154), são expulsos de Roma dois filósofos epicuristas. Em 168, Crates de Pérgamo ali permanece, e com ele introduz-se em Roma o espírito filosófico, juntamente com a filologia e a gramática que ensina. Pouco depois, em 155, Diógenes da Babilônia, Carnéades de Cirene e Critolau da Fasélida impressionam a aristocracia romana ${ }^{3}$ (Catão negativamente embora) com as suas idéias e a sua arte. $O$ fato é que se desenvolve nos romanos o hábito da reflexão crítica, de que é exemplo um novo tipo de história, diferente do simples registro dos fatos, e a aspiração à humanitas.

Na verdade, a noção de humanitas haveria surgido pela primeira vez em Roma numa comédia de Terêncio, ${ }^{4}$ que naturalmente apenas traduziria Menandro. A idéia, no entanto, vai sendo retomada e enriquecida a seguir, até transformar-se a ciuitas romana em ciuitas humana (cf. Grimal, 1960, 89).

A oposição nacional à assimilação da cultura helênica, manifestando-se tanto contra a filosofia em particular como contra todas as influências em geral, nada pode fazer em face do processo, que é irreversível. Assim é que a obra de Catão, o Velho (234-149), arauto da oposição, traz marcas de estilo helênico.

É cada vez maior em Roma o número de sábios. As antigas Escolas, porém, a Peripatética e a Acadêmica, não podem difundir-se por não conterem regras de 
comportamento. Como a filosofia se torna em uma ciência da moral que, de certo modo, cumpra o ofício da religião, e para tanto se baseie numa concepção do homem e do mundo que se apresente como verdadeira, o estoicismo e o epicurismo dominam o século de Lucrécio: o primeiro a procurar a salvação da sociedade pela dependência do homem a uma Providência divina, o segundo a procurar a liberdade do homem, tornando-o seu próprio senhor.

Cícero registra a presença de uma literatura epicurista, cujos responsáveis seriam os filósofos Caio Amafínio, Caio Rabírio e Tito Cátio, citados nominalmente (Cic., Fam. XV 16 \& 19; Acad. rel. I 2, 5-6). Não tem sido possível determinar com exatidão o terminus a quo dessa presença. Fins do século II? Início ou meados do século I? Também é Cícero quem afirma que é grande a divulgação do epicurismo para além das fronteiras da Vrbs (Cic., De fin. II 15, 49), com a qual afirmação concorda Lucrécio (Lucr. V 19-21).

A filosofia do Jardim, que, segundo parece, atingiu primeiro o povo, chega à aristocracia, e muitos são os romanos epicuristas. Entre os mais representativos, Tito Pompônio Ático, Mânlio Torquato, de quem Cícero faz expositor da doutrina em De finibus bonorum et malorum, Júlio César, Trebácio Testa, amigo e companheiro de Júlio César na Gália, Lúcio Calpúrnio Pisão, sogro de Júlio César, entre tantos outros.

Ático afastado da política. Pisão entre o epicurismo e a política. Torquato conciliando epicurismo e política. Júlio César entregue à luta. Entre eles ou, mais provavelmente, afastado deles, Tito Lucrécio Caro, autor do De rerum natura, o grande poema didático e filosófico, um dos mais belos da literatura ocidental, documento epicúrio por excelência, visto que a obra do Mestre, de mais de trezentos volumes, quase toda se perdeu.

Três são os pontos de encontro do epicurismo no século I a.C.: Atenas, Roma e Nápoles.

Em Atenas, encontra-se Fedro, que durante a primeira guerra de Mitridates se refugiara em Roma e conquistara a amizade de Cícero e Ático, amizade que conservou mesmo depois de voltar a Atenas. Em Nápoles, Sirão, mestre de Vergílio. Filodemo de Gádara, discípulo de Zenão de Sídon em Atenas, encontra Sirão em Nápoles e, tal como este, consegue influenciar os seus contemporâneos. Cícero os considera os representantes mais autorizados da Escola Epicurista (De fin. II 35, 119). Filodemo estabelece-se em Roma por volta de 70 e dedica-se a divulgar a filosofia, apresentando as doutrinas gregas; e o faz do ponto de vista do epicurismo. Da sua obra restam fragmentos poéticos e um libelo, Perì tô̂ kath' Hómeron agathô̂ 
basiléos ("O bom rei segundo Homero"), encontrados na biblioteca de Herculano, que segundo parece lhe pertencia. Poeta, expressa nos seus epigramas sentimentos que são os do epicurismo. Filósofo, reproduz textualmente palavras de Epicuro.

Filodemo parece ter grande importância na caracterização do epicurismo tal como o pratica Júlio César, que se afasta do láthe biósas e procura o sucesso e a glória ou, como diz Rambaud (1969, 415), pratica o láthe biósas ao dissimular nos Comentários a sua vida particular e apresentar uma figura que traduz a sua ideologia: figura através da qual se pode reconhecer uma doutrina que, se pela firmeza pode lembrar o estoicismo, no entanto é plena de sentido epicúrio.

É preciso, antes de mais, lembrar que o láthe biósas não exclui a noção de Pátria, embora a sociedade humana não exista por natureza e a comunidade estatal não implique obrigação para o sábio, e embora o Mestre não se tenha interessado pela vida política de Atenas. (Aliás, não apenas não se interessou como desaconselhou a atividade política: cf. Sent. Vat. 58).

Mas estamos em Roma. E Lucrécio que escreve (V 1117-9):

se governássemos nossa vida segundo a razão verdadeira,

a grande riqueza para o homem consiste em viver parca

e tranqüilamente $[. .$.$] ;$

também escreve (I 41-2):

nem podemos nós escrever tranqüilamente estes versos nos maus momentos da Pátria, nem a descendência ilustre de Mêmio pode faltar, em tais circunstâncias, ao interesse comum.

Eis em linhas gerais o quadro do epicurismo em Roma quando nasce o De rerum natura, monumento de arte a pregar a tranqüilidade, a condenar a inveja, a ambição, a paixão política!

Pois bem. Voltemos ao estoicismo.

Três são as suas fases, e nem sempre há convergência quanto aos pormenores dos postulados nas três fases.

Na primeira, nos séculos IV e III a.C., encontram-se Zenão de Cício, Cleantes de Assos e Crisipo de Solos. 
Na segunda fase, nos séculos II e I a.C., encontram-se Diógenes da Babilônia, que esteve em Roma em 155, enviado por Atenas, Antípatro de Tarso, que definiu a moralidade como "uma escolha refletida, contínua e sem esmorecimento, dos preferíveis naturais", e também Panécio de Rodes e Posidônio de Apaméia.

Entre a segunda e a terceira, isto é, entre o século I a.C. e aproximadamente o ano 22 da nossa era, cita-se Marco Manílio, cujo poema, Astronomica, é pleno de sentido estóico.

Na terceira fase, nos séculos I e II da nossa era, encontram-se, primeiro, Quinto Sêxtio e o filho, Cláudio Musônio Rufo e Lúcio Aneu Sêneca. Mais tarde, o frígio Epicteto e o imperador Marco Aurélio.

Há uma evolução do primeiro ao terceiro estoicismo, que se liga menos à física e mais à moral. Não entrarei em pormenores dessa evolução; apenas veremos, em linhas gerais, o que significa o estoicismo.

Vamos por partes.

Vimos Zenão de Cício, o fundador da Escola, discípulo de Crates de Tebas, o Cínico (IV a.C.). Zenão põe todas as condições de felicidade unicamente na uirtus ("valor, coragem, autodomínio"), una e indivisível (cf. Cic., Luc. 138 et seqs). Autêntico modelo de coerência, os atenienses prestaram-lhe honras fúnebres, porque ele, tendo vivido segundo seus próprios ensinamentos, fora um modelo para todos.

Cleantes de Assos (c.330-c.231) enfatiza mais o aspecto religioso da doutrina e escreve um hino a Zeus, não ao Deus da mitologia mas ao espírito Razão, autor do universo. Diz o hino mais ou menos o seguinte:

Infelizes, querendo sempre adquirir bens, [os homens] não vêem e não ouvem a lei comum de Deus; se lhe obedecessem com inteligência levariam vida feliz. Mas, insensatos, correm de um a outro mal [...] esforçando-se por encontrar exatamente o contrário daquilo que esperavam. Mas, ó Zeus, Pai de todos os bens [...] salva os homens de sua infortunada ignorância, expulsa-a de sua alma, ó Pai, e faze com que obtenham o pensamento sobre o qual te apóias para governar todas as coisas com justiça, a fim de que, sendo nós mesmos honrados, nós te rendamos honras, cantando as tuas obras, como convém a um mortal, visto que não há para os homens nem para os Deuses maior honra que cantar a lei comum e eterna, na justiça (Stob., Ecl. I 2, 12, ap. Brun, 1976, p. 68).

Este hino deve dar-nos uma idéia de sua moral, ou de seu pensamento, do ponto de vista da moral e da religião, e do valor da inteligência, da justiça e da lei eterna. 
Crisipo de Solos (c.280-204) é aquele muito conhecido por causa da explicação da liberdade humana a partir do, digamos, "comportamento" de um cone e de um cilindro. É preciso dizer, antes, que a liberdade apresenta um dos grandes paradoxos do estoicismo. Entretanto, vejamos. Crisipo quer salvaguardar a liberdade humana "conservando o destino e evitando a necessidade". A verdade é que, em qualquer momento da doutrina, o estoicismo visa a salvaguardar a liberdade humana. E Crisipo distingue das causas que dependem de nós as que não dependem. Por exemplo: não depende de nós que chova ou faça sol, mas depende de nós o nosso comportamento diante desses fatos exteriores a nós. Assim, também, é graças a um impulso exterior que um cone ou um cilindro se movem; mas depende só deles o modo como se movem: é graças à sua própria natureza, suapte natura, suapte ui et natura, como diz Cícero em De fato $(18,42 ; 19,43)$, que um cilindro rola e um cone gira. O estoicismo de Crisipo entende que esse exemplo salvaguarda a liberdade humana. Ora, não é livremente que um sólido é um cilindro ou um cone, mas para o estoicismo cada indivíduo é o que é, e a liberdade consiste em agir segundo o inevitável ou, melhor dizendo, consiste em querer, ou mesmo em escolher, o inevitável.

Isto põe frente a frente Édipo e Enéias. $\mathrm{O}$ primeiro escolhe contra o destino: e o cumpre vencido; o segundo escolhe a favor do destino: e o cumpre vencedor. Kitto, em sua obra Os gregos, afirma que há um poder mais forte ainda que os Deuses: anánke, "o que tem de ser", ou Moîra, "a distribuidora", e que esta concepção contém o germe da religião e da ciência (Kitto, 1960, 322). Mas Crisipo distingue destino e necessidade. Como explica Robin, esta, a necessidade, exerce uma imposição; aquele, o destino, une fatos que são em si mesmos possíveis, isto é, "o destino é um sistema eterno e rigoroso" de possíveis solidários (Robin, 1963, 165). Crisipo chama a esses possíveis solidários confatais, isto é, fatos destinados a produzir-se se outros se produzirem, e solidários com eles. Por exemplo, se é fatal que Édipo nasça de Laio, é confatal que Laio tenha relações com uma mulher. Esses confatais visam a obstar ao argumento preguiçoso. Este argumento preguiçoso (argòs lógos) consiste no seguinte raciocínio dos megáricos: se é teu destino curar-te, vais curar-te quer chames ou não o médico. Igualmente, se teu destino é não te curares, não te curarás, quer chames ou não o médico. Portanto, é inútil chamares o médico. E Crisipo respondia a esse argumento com a teoria dos confatais (suneimarména, confatalia: cf. Brun, 1976, 87). Bem mais tarde, Sêneca, traduzindo o hino de Cleantes a Zeus, diz que os destinos guiam aquele que não lhes resiste e arrastam o que lhes resiste. Assim, sábio é o que escolhe de acordo com o destino. Ao fim e ao cabo, como diz Robin $(1963,167)$, só há para os estóicos um único indivíduo, o Todo, ou Deus; e a nossa vontade é o reflexo da sua vontade. 
O segundo estoicismo tem, em grande parte, o seu cenário em Roma.

Por volta de 150, chega à Vrbs Panécio de Rodes (c.180-c.110), o fundador do estoicismo chamado médio. Discípulo de Antípatro de Tarso, que escrevera um livro sobre o cosmos e afirmara que a substância de Deus é semelhante ao ar (DL VII 148), Panécio, admirador de Aristóteles, tem tendência ao ecletismo. Libera o estoicismo do domínio da necessidade e insiste sobre a liberdade do homem e a moral voltada para a ação, o que vem ao encontro do sentimento romano. Abremse-lhe as portas da aristocracia, e Cipião Emiliano, o Segundo Africano, vencedor de Cartago em 146, e Lélio, o cônsul de 140, recebem-no como amigo em seu círculo, o chamado Círculo dos Cipiões, assim como em 168 havia sido recebido o historiador Políbio (c.202-120), que veio a ser o tutor dos filhos de Emílio Paulo, um dos quais era o próprio Cipião Emiliano.

Certamente é para Roma que Panécio escreve o seu Perì toû kathékontos, que influenciará o ciceroniano De officiis. (Kathékon é o "comportamento conveniente".)

O que a Vrbs, voltada desde sempre para a política e o direito, assimila do estoicismo de Panécio é principalmente a idéia de virtude ("autodisciplina, autodomínio"), pedra angular da moral romana. O sábio é o que possui a uirtus, o que tem uma regra de ação. Na verdade, o sábio, como explica Dumont, é ao mesmo tempo um homem que medita e um homem que age: meditando, compreende as razões da harmonia universal; agindo, concorre para essa harmonia (Dumont, 1968, 114). Convencido de que há uma vontade universal e de que a sua vontade a reflete, o estóico sente-se indicado para governar.

Convém destacar que das noções de uirtus, lex e ratio, "autodisciplina, lei e razão", decorre um sistema ético, em que é forte a dominante social; e convém, ao mesmo tempo, lembrar que ao Círculo dos Cipiões pertencem os Gracos, Tibério (163-133) e Caio (154-121), netos de Segundo Africano. E os ideais dos Gracos todos conhecemos.

Pois bem. A seguir os romanos são bastante influenciados pelas idéias de Posidônio de Apaméia (c.135-c.51), discípulo de Panécio e seu sucessor na Escola de Rodes, onde em 77 o vão encontrar Cícero e Pompeu.

Posidônio, assim como o seu mestre, é de tendência eclética. De acordo com ele, admite no homem uma vida instintiva, condição natural. Aliás, essa noção de "vida instintiva" não é criação de Panécio. Primeiro: os seres vivos distinguem desde o nascimento o que é conforme à sua natureza ou, melhor, o que concorda com a natureza e o que não concorda. Segundo, os estóicos, desde Crisipo, distinguem 
vários estudos no campo da moral. Entre outros, o estudo dos comportamentos convenientes (kathékonta), o estudo do bem supremo, fim para o qual tendemos todos (télos), o estudo da uirtus e um estudo das tendências (hormái).

A tendência fundamental é o instinto de conservação, que leva o ser vivo a procurar o que lhe convém e, como diz Brun, lhe dá uma consciência de si mesmo, que lhe permite viver de acordo com sua natureza (Brun, 1976, 93).

Ao contrário de Panécio, porém, Posidônio insiste na interação dos fatos, reduzindo tudo à unidade, através do conceito de simpatia: todas as partes do cosmos relacionam-se e influenciam-se umas às outras. Posidônio é fiel à teoria do lógos estóico. Aceita, porém, todos os Deuses e cultos, a astrologia e a adivinhação. E a alma é, para ele, emanação do sol: não nasce e não morre com o homem. Aliás, uma alma imortal, emanação do sol, não traz muita novidade. Vimos que para o estoicismo, de maneira geral, a alma é parcela do lógos divino, e esse espírito ou razão universal é Deus: portanto, eterno; e a alma, parcela sua, tem de ser nada menos que imortal.

(Abro um parêntese para a adivinhação. Visto que a mesma ordem da natureza voltará sempre a realizar-se, necessariamente, é possível prever o futuro, e a adivinhação no estoicismo é, basicamente, uma ciência.)

Nesse Io século antes de Cristo não se pode deixar de mencionar Marco Túlio Cícero (106-43).

O Orador, a partir de 55, dedica-se a escrever os seus diálogos. Surge em 54 De Republica, pleno de platonismo, de estoicismo e de romanidade (cf. 5,7;6,15), a lutar expressamente das primeiras às últimas páginas contra a filosofia do Jardim; a exaltar, das primeiras às últimas páginas, a dedicação à Pátria (cf. I 1; 6, 13.26), e a procurar explicar a realidade romana, em busca de uma solução racional para a sua história. De Republica, precedido por De oratore (em 55), é seguido por De legibus (52-51): Cícero, o político, procura na filosofia uma norma. Há um belo passo no livro $\mathrm{V}$ de Tusculanae disputationes $(2,5)$, que lembra esta última afirmação:

Ó filosofia, guia da vida, ó tu que procuras a virtude, que expulsas os erros, sem ti o que poderíamos ser, não apenas nós mas toda a vida dos homens? Tu é que deste à luz as cidades, tu é que chamaste à vida em sociedade os homens esparsos [...].

Nicolet \& Michel $(1960,20)$ chamam a Cícero moralista politico e explicam bem os seus anseios. Marco Túlio parece bastante imbuído de pensamento estóico, 
principalmente, talvez, após a morte de Catão de Útica, em 46. Na primavera desse ano, escreve Paradoxa stoicorum. E, após os idos de março, enquanto divulga e/ou lê os discursos contra Antônio e tenta mudar o destino da Vrbs, continua a dedicar-se aos seus diálogos: expõe as diferentes doutrinas filosóficas e o comportamento do sábio. Embora critique certas noções do estoicismo, por exemplo, a adivinhação no II livro de De diuinatione, ou teses várias no IVo livro de De finibus ou, ainda, o fatalismo em De fato, adota a moral estóica, a qual, segundo afirmei, caminha ao encontro da moral romana. A sua obra é, de fato, manancial riquíssimo para o estudo do estoicismo. E o seu último diálogo, De officiis, considerado seu testamento moral, tem, como vimos, o seu modelo em Panécio.

Vejamos, segundo Cícero, os paradoxos dos estóicos.

1․ O Belo moral é o único bem, idéia que se atribui a Zenão e Crisipo, e que Cícero apresenta e depois critica em Finibus (III \& IV), Tusculanae (V), Officiis (I \& III).

$2^{\circ}$. A virtude basta à felicidade, princípio que se atribui principalmente a Crisipo e que Cícero apresenta e depois critica em Finibus (III \& IV).

3․ Todos os erros são iguais, os acertos, também, o que o Orador refuta em Finibus (IV) e ridiculariza em Pro Murena (61) mas sustenta em Tusculanae (V).

4. Todos os estultos deliram: o Autor focaliza a tese em Pro Murena (61), Oratore (III 65), Tusculanae (IV 54) e combate em Finibus (IV 20 et seqs).

5․ Todos os sábios são livres, e todos os estultos, escravos, afirmação que se completa: "escravos de suas paixões", e se atribui a diversos estóicos.

6. Só o sábio é rico: Cícero, pensando em Crasso, ridiculariza tal sábio.

Os estudiosos lêem esses paradoxos à luz do pensamento de outros filósofos, notadamente Sócrates.

A terceira fase do estoicismo abandona a lógica e a física em benefício da moral. O seu cenário é principalmente Roma, sob um regime de terror. A Augusto sucedem Tibério, Calígula, Cláudio, que desposando Agripina Minor a eleva ao poder, e Nero. Desse momento, citam-se os dois Sêxtios, Caio Musônio Rufo, exilado por Nero, e Lúcio Aneu Sêneca, preceptor do imperador. Mais tarde, o frígio Epicteto e o imperador Marco Aurélio.

Quinto Sêxtio e o filho haveriam praticado o "ascetismo moral" numa espécie de estoicismo cínico, de que há raros documentos. Seu discípulo, o pitagórico Sótion de Alexandria, teria influenciado grandemente Sêneca. O Cordovês, que estudara também o estoicismo de Átalo, conhecia igualmente as máximas morais do epicurismo. Todas essas influências caracterizam esse neo-estoicismo, de que Sêneca é o expoente. 
Contemporâneo de Sêneca, embora tenha nascido trinta anos mais tarde, é o poeta satírico Pérsio Flaco, que nasceu em 34 e morreu em 62. Pérsio é estóico e dogmático. São os seguintes os temas de suas sátiras: 1a) contra a poesia do seu tempo; 2a) sobre a verdadeira religião: termina dizendo o que é que se deve oferecer aos Deuses: "uma alma em que reinem harmoniosamente o direito humano, o divino, um espírito puro e um coração honrado e generoso", idéia que não é exclusiva do estoicismo, como sabemos todos; $3^{a}$ ) contra a preguiça dos que interrompem os estudos; 4a) contra os que são juízes do próximo e se esquecem de ser juízes de si mesmos, e contra os que pretendem governar sem ter maturidade e moral suficientes para tanto; 5a) sobre a liberdade, do ponto de vista do bom-senso: isto é, só é livre o que não obedece às paixões: à ambição, à paixão amorosa, o que também não é criação do estoicismo; 6a) sobre a avareza.

Depois do Cordovês, encontram-se como eu disse, o escravo frígio Epicteto (50/60-120/140) e, mais tarde, o filho adotivo de Antonino, o Pio, imperador Marco Aurélio, que governou de 161 até a morte, em 180.

Epicteto, o Frígio, tinha menos de dezoito anos à morte de Nero, e viveu sob os Flávios e os primeiros Antoninos. Sua doutrina foi-nos conservada pelas anotações de Flávio Arriano (c.95-175), seu discípulo. Epicteto parece acreditar no governo do mundo por uma Providência onisciente. Atribui-se-lhe o conselho "suporta e abstém-te", que deve levar o homem à tranqüilidade.

E o imperador Marco Aurélio deixou uma coleção de memórias, as Meditações, algumas das quais, se não estão em desacordo com o estoicismo antigo, no entanto fazem concessões à Escola "rival"; por exemplo:

"Tanto Alexandre da Macedônia como seu cavalariço tiveram o mesmo destino com a morte: ou foram reabsorvidos no mesmo princípio gerador", o que é estóico, "ou se dispersaram com os átomos", o que é epicúrio (trad. de W. Li).

Voltemos ao grande expoente desse estoicismo romano, Lúcio Aneu Sêneca (c.4 a.C.- 65), um dos três filhos de Sêneca, o Retor. Nasceu sob Augusto e viveu sob Tibério, Calígula, Cláudio e Nero. Foi, pois, contemporâneo de Fedro, Pérsio, Lucano, seu sobrinho, também estóico, e provavelmente Quinto Cúrcio e Petrônio. Foi, também, lídimo representante de sua época, marcada principalmente por essa filosofia estóica híbrida, pelas escolas de retores, por atitudes moralizantes em face dos desmandos e da crueldade da casa real: o fato é que a filosofia consola. 
Sêneca é uma figura discutida. Para alguns estudiosos, não foi um eclético, segundo geralmente se crê, pois o fundamento e as grandes linhas de seu pensamento são estóicos; para outros, foi eclético: de acordo com Bayet $(1965,318)$, mais ainda que Cícero porque, no que diz respeito à conduta psicológica, o caminho importa menos que o fim. Ao meu ver, o que realmente o preocupa é o comportamento humano: tendo conhecido a vida em família, a vida na corte, a seguir o exílio (Córsega, de 41 a 49) e depois o poder, certamente se perguntaria como deve o homem comportar-se para ser feliz.

Quanto ao seu estilo, são concordes os estudiosos ao afirmar que é "vivo, penetrante, incisivo", o que fica bem claro, por exemplo, na segunda parte de De uita beata (17 et seqs). São também concordes no julgamento positivo de sua obra, embora com pequenas discordâncias. Segundo Bayet $(1965,317)$, revela-se ele e impõe-se pela criação filosófica. Segundo Bickel $(1982,453)$, as cartas são sua obraprima. O mesmo pensa Herrmann $(1924,534)$, embora considere a língua das tragédias mais tradicional que a das obras filosóficas. Ainda assim, parece-me difícil emitir um julgamento generalizante sobre a sua prosa. De brenitate uitae, por exemplo, cuja leitura é interessante e agradável, não resiste a uma análise literária. As cartas de consolo a Márcia e principalmente a Políbio são de valor literário discutível.

O que me parece importante assinalar é que Sêneca, tanto na prosa como nas tragédias, está envolvido com a sua filosofia de vida, envolvimento que ele declara em Naturales Quaestiones, por exemplo, e que realmente está em todos os seus escritos: "A todos os atos e palavras deve misturar-se algo de útil" (II 59, 2).

De fato, o que preocupa é o modo de viver. Na carta 23 a Lucílio, por exemplo, encontra-se o disce gaudere, "aprende a alegrar-te". Antes, na mesma carta $(23,2)$, lê-se que "chegou ao ponto mais alto aquele que sabe com que alegrar-se e cuja felicidade não depende do poder alheio" (verdade que Medéia e Fedra ignoraram).

O homem deve agir em consonância com o céu, o conhecimento determina a ação, e o homem une-se a Deus pela uirtus. Deve dominar a sua própria natureza e viver de acordo com a natureza que se identifica a Deus (De. breu. uit. 14, 2; De uit. b. 3, 3). O sumo bem é, para Sêneca, um espírito que despreza os acasos da sorte e se compraz na virtude, livre do medo e do desejo, graças à razão (De uit. b. 4, 2-5, 1). Acredita ele que há uma força vital, spiritus, o "ar" ou, melhor, a "energia", princípio fundamental de sua filosofia, e que age no ânimo (animus), e o põe em movimen- 
to. De energia são plenas as suas personagens e tudo o que tem vida e, igualmente, a terra (N. Q. II 9, 4; cf. Oltramare, 1929, xxii).

Para terminar, abro um parêntese para a liberdade.

Sêneca deseja dar lugar ao livre arbítrio e, em Naturales Quaestiones, promete estudar o tema. Não cumpre a promessa e ficamos, aí, com as teorias dos que ele pretende combater (II 38, 3). No diálogo De prouidentia $(5,7)$, lê-se:

Os destinos nos conduzem e o tempo que resta a cada um é determinado pelo instante do nascimento. Uma causa depende de outra, e a longa ordem das coisas arrasta os acontecimentos particulares e gerais.

Adiante $(5,8)$, lê-se que ao homem cumpre entregar-se ao destino. E que o próprio Júpiter, que uma vez ordenou os destinos, a eles obedece. E Sêneca se compraz em citar, mais de uma vez, por exemplo em Vita beata $(19,1)$, as palavras de Dido, às portas da morte: "Vivi: e percorri o caminho que a Fortuna me dera" (Aen. IV 653). Por outro lado, lê-se, também em Vita beata $(15,7)$, que "obedecer a Deus é a liberdade".

Que quer isto dizer? Arranca-se o homem às malhas do destino quando obedece a Deus? Mas Deus é para Sêneca alma e espírito do mundo, de que é também senhor e artífice; dele tudo depende: identifica-se ao fatum, pois é ele a causa das causas; identifica-se à Providência, pois o mundo é provido pela sua sabedoria para desempenhar as suas funções; identifica-se à natureza, pois dele tudo nasceu e pelo seu espírito vivemos (N. Q. II 45, 1-2). Lê-se, ainda, na mesma obra, Naturales Quaestiones, que Júpiter não está presente a tudo mas deu a todos a mão, a força e a causa (II 46).

Aí me parece estar a brecha para a liberdade humana. Como assinala Herrmann (1924, 495), Sêneca estava convencido de que o homem tem a liberdade de escolher o seu comportamento, e de que a luta contra as paixões é sempre possível: a alma é poderosa e a vontade determina o ato. Ao contrário do herói trágico na Grécia, o herói de Sêneca escolhe o seu caminho. Se obedece a Deus, se age de acordo com a razão e a uirtus, o homem foge aos laços fatais (o que Medéia e Fedra não fizeram).

\section{Notas}

* Professora Doutora de Língua e Literatura Latina do Programa de Pós-Graduação em Letras Clássicas da FFLCH-USP. 
1 No que tange à cosmologia, o epicurismo é herdeiro de Demócrito e o estoicismo o é de Heráclito. Quanto ao valor dos sentidos para a teoria do conhecimento, Demócrito e Heráclito são ambos céticos.

2 Cf. DL VII 143.156-7. Zenão de Cício e Posidônio de Apaméia definem a alma como um "sopro quente" (pneûma enthermón).

3 Cf. Cic., De or. II 37, 155. Os três filósofos representam respectivamente o estoicismo, a Nova Academia e o Liceu.

4 Heaut. 77: homo sum: humani nil a me alienum puto.

\section{REFERÊNCIAS Bibliográficas}

ANDRÉ, J.-M. La philosophie à Rome. Paris: PUF, 1977.

BAYET, J. Littérature latine. Paris: A. Colin, 1965.

BICKEL, E. Historia de la literatura latina. Madrid: Gredos, 1982.

BRUN, J. L'épicurisme. Paris: PUF, 1974.

-. Le stoicisme. Paris: PUF, 1976.

DUMONT, J.P. La philosophie antique. Paris: PUF, 1968.

GRIMAL, P. La civilisation romaine. Paris: Arthaud, 1960.

HERRMANN, L. Le théâtre de Sénèque. Paris: "Les Belles Lettres", 1924.

KITTO, H. D. F. Os gregos. Coimbra: A. Amado, 1960.

NICOLET, C. \& MICHEL, A. Cicéron. Bourges: Du Seuil, 1960.

OLTRAMARE, P. Introduction. In: SÉNÈQUE. Questions naturelles. Paris: "Les Belles Lettres", 1929.

RAMBAUD, M. César et l'épicurisme d'après les Commentaires. Actes du VIII Congrès.

Paris: "Les Belles Lettres", 1969.

ROBIN, L. La morale antique. Paris: PUF, 1963.

-. La pensée grecque. Paris: A. Michel, 1948.

NOVAK, Maria da Gloria. Stoïcisme et épicurisme à Rome.

RÉSUMÉ: Tout homme veut être heureux. Le stoïcisme et l'épicurisme, qui sont des philosophies de la nature, des philosophies morales, donnent des réponses à l'incertitude de celui qui rêve la sérénité de l'âme. D'habitude on les oppose, puisque leurs postulats et leurs normes de vie sont tout à fait 
différents. Le stoïcisme vise le salut de la société moyennant la dépendance de l'homme à la Providence; l'épicurisme, la liberté de cet homme. Si le Dieu stoïcien, la Raison, a créé le monde et le gouverne, les Dieux épicuriens, qui sont le modèle - parfait - de la conduite du sage, ne l'ont pas crée et ne le gouvernent pas.

MOTS-CLÉS: Rome; épicurisme et stoïcisme; liberté et destin; mortalité et immortalité. 